\title{
AWANGARDA TRADYCJI. GLOS W SPORZE \\ O TOŻSAMOŚĆ WSPÓŁCZESNEGO MĘŻCZYZNY \\ KS. ADAMA RYBICKIEGO W PRACY OD ANTROPOLOGII DO DUCHOWOŚCI MĘŻCZYZNY. ŹRÓDEA, KONCEPCJE, PERSPEKTYWY, WYDAWNICTWO „BERNARDINUM”, PELPIN 2020, SS. 303. ISBN 978-83-8127-578-1
}

Świat nauki nieustająco poszukuje nowych rozwiązań nie tylko w świecie technologii, ale także w świecie idei i ludzkiej myśli. Elementy nowości, postępu i oryginalności stanowią ważne kryterium oceny także wszelkich projektów o charakterze humanistycznym i społecznym. Czy jednak rzeczywiście ciągle potrzebujemy nowości, alternatyw budowanych w oporze, w kontrze do tradycyjnego, zastanego, „starego”? Czy istotnie osiągnięcia poprzednich pokoleń należy kontestować tylko dlatego, że należą do przeszłości? W świecie technologii i myśli technologicznej z pewnością musi dokonywać się postęp niemal rewolucyjny - tak gwałtownie zmienia się nasza wiedza o świecie materialnym, ale czy zmiana zachodzi równie szybko $\mathrm{w}$ wiedzy o tożsamości człowieka?

Pytania takie z pewnością warto zadawać w humanistyce i rozważać szczególnie na gruncie pedagogiki, która niezależnie od bieżących klasyfikacji jest jednocześnie nauką humanistyczną i społeczną. Odcinanie się od przeszłości jest jak odcinanie się od korzeni, co - podążając dalej za metaforą - może być niebezpieczne, gdyż rodzi ryzyko odcięcia od ważnych, życiodajnych i myślotwórczych źródeł. Odcinanie się od przeszłości może polegać także na zakrywaniu pewnych elementów wiedzy, przysłanianiu ich i odsuwaniu w niebyt. Tak powstają białe plamy nie tylko na kartach historii. Zbigniew Kwieciński wprost zwraca uwagę na zjawisko, które nazywa „przecięciem pamięci wewnętrznej pedagogiki” ${ }^{1}$, obrazowanym np. w niewykorzystywaniu

1 Teza wygłoszona przez Zbigniewa Kwiecińskiego w wystąpieniu Pytania o kanon studiów pedagogicznych w ramach Konferencji władz wydziałów kształcących na kierunkach pedagogicznych w publicznych szkołach wyższych nt. „Jakość edukacji akademickiej w naukach o wychowaniu a wielostopniowość studiowania”, Lublin-Kazimierz Dolny, 12-14 października 2010. 
i niesięganiu do prac przedwojennych autorów. Współcześnie wielu pedagogów ze zdziwieniem odkrywa, że kilkadziesiąt lat temu polscy humaniści głosili tezy, które obecnie wydają się być nowoczesne i stają się modne. W niemal każdej subdyscyplinie pedagogicznej można obecnie wskazać ciągłość myśli, której źródła biją jeszcze przed II wojną światową. Aleksander Nalaskowski pisze:

Każdy czas ma swoją tradycję. [...] Pedagogika polska wraca często do Hessena, Sośnickiego, Mysłakowskiego i Korczaka. Awangarda nierzadko polega na zaskakującym nawrocie ku tradycji [podkreślenie A.S.-B.]².

Jak daleko zatem, będąc w awangardzie, można sięgać wstecz? Odpowiedź na tak postawione pytanie wcale nie jest oczywista. Awangarda bowiem, poszukując nowych rozwiązań ideowych, może także w twórczy sposób dokonać rekonstrukcji myśli wywiedzionej z tradycji; myśli, która nie będąc aktualnie wiodącym czy modnym nurtem, poprzez zakorzenienie w wartościach uniwersalnych nie traci nic na swojej ważności. Można zatem sięgnąć do myśli sprzed dwóch tysięcy lat, w ten sposób np. twórcze odczytanie tekstu biblijnego i rekonstrukcja kategorii męskiej tożsamości może stać się awangardą współczesnej humanistyki.

Książka ks. dr. hab. Adama Rybickiego, prof. KUL jest oryginalnym studium teoretycznym wpisującym się w światowy dyskurs współczesnej humanistyki na temat tożsamości człowieka. Autor podjął się bardzo trudnego zadania związanego z rekonstrukcją kategorii męskości oraz dekonstrukcją jej znaczeń uwikłanych w spory natury filozoficznej, a nierzadko i ideologicznej. Adam Rybicki prezentuje w swej pracy bardzo solidny warsztat naukowy, oparty na szerokich studiach interdyscyplinarnych. Badania nad tożsamością mężczyzny i związaną z nią kategorią męskości, budowaną zwłaszcza na solidnych fundamentach antropologii i teologii, bez wątpienia należą do społecznie potrzebnych, nowatorskich prac odważnej humanistyki. Kim bowiem jest lub może czy powinien być współczesny mężczyzna? W jakim kluczu, w jakim kontekście kulturowym odczytywać istotę jego tożsamości w czasach naznaczonych migotaniem znaczeń, gdzie łatwo o tożsamości rozmyte, miękkie, chowające się za filozofią ponowoczesną, ponowoczesnymi wzorcami kultury oraz ruchami społecznymi promującymi kulturowe rozumienie płci człowieka? Kim zatem jest współczesny mężczyzna?

Ksiądz Adam Rybicki przyjął założenie, iż tożsamość męska jest naturalną bazą dla całej postawy duchowej człowieka, dlatego główną osią interpretacyjną swych studiów uczynił teologię duchowości. W swej pracy podejmuje zatem problem męskiej tożsamości i męskiej duchowości, które wzajem siebie kształtują. Nowatorstwo prezentowanego podejścia leży w takim prowadzeniu narracji i konstrukcji teologicznego modelu męskości, by był on na tyle uniwersalny, aby mogły czerpać z niego także kobiety. Duchowość mężczyzny jest bowiem duchowością Człowieka,

2 Aleksander Nalaskowski, „Alternatywność szkoły jako kolejny etap jej kryzysu”. W: tegoż, Widnokregi edukacji (Kraków: Impuls, 2002), 325-326. 
w której to męska i kobieca duchowość splatają się w dopełniającą wzajem całość. Uważne wczytanie się w pracę udowadnia, iż pozorna opozycja męskość/kobiecość - odczytywana zwłaszcza i intepretowana na gruncie kulturowym przez nurty feministyczne i gender study - na gruncie teologii duchowości i katolickiej nauki społecznej przełamuje sztuczne podziały i w różnicy wskazuje drogę zespolenia. Tradycyjny model męskości ukształtowany na wzór chrześcijańskiej antropologii nie musi wcale oznaczać stereotypu tradycyjnego mężczyzny uosabiającego nieuzasadnioną dominację, agresję czy przemoc. Jak podkreśla ks. Adam Rybicki, teologia, a zwłaszcza teologia duchowości,

zgodnie z zasadą nova et vetera (łac. rzeczy stare i nowe) może (i powinna) w budowaniu koncepcji męskości nie tylko docenić stare, ale i skorzystać z tego, co nowe, wejść w dobrze pojęty dialog z naukami humanistycznymi [...]. Nie można już dzisiaj dać teologicznej odpowiedzi na pytanie o męską tożsamość (a tym bardziej duchowość), ignorując osiągnięcia antropologii, psychologii, socjologii czy kulturoznawstwa ${ }^{3}$.

Praca podzielona jest na trzy rozdziały: źródła, koncepcje i perspektywy, które tworząc spójną całość, prowadzą Czytelnika przez drogę poszukiwań odpowiedzi o istotę męskości. Część pierwsza to Źródła, w której Autor opisuje źródła swych naukowych badań, inspiracji i refleksji. Zwraca uwagę na ważne społecznie problemy związane z kategorią męskości, które powinny być rozwiązywane także na gruncie teologii duchowości, jak np. kryzys męskości wyrażający się brakiem i patologią ojcostwa $a^{4}$, toksycznymi postawami ojców wobec synów ${ }^{5}$, zranienia męskości chłopca w rodzinie, swoista abdykacja emocjonalna ojca i wycofanie się z relacji rodzinnych, a zatem porzucenie tożsamości męża i ojca na rzecz dryfowania w kierunku tożsamości biznesmena, wymagającej bycia twardym i bezlitosnym w walce o dobra materialne. Kryzysu męskości można upatrywać nie tylko w perspektywie psychologicznej, ale także kulturowej, związanej z zanikiem inicjacji i obrzędów przejścia do dojrzałości ${ }^{6}$, które odbierają mężczyźnie możliwość przeżycia liminalnego, generującego rozwój i wejście w duchową wspólnotę mężczyzn. Źródeł kryzysu męskiej tożsamości Autor upatruje także w sporach ideologicznych, manifestach feministycznych i upadku tradycyjnego paradygmatu męskości. Zwraca jednak uwagę, że błędem jest upatrywać w feminizmie jednego z najważniejszych czynników zaburzonej tożsamości męskiej, gdyż feminizm stanowi raczej kulminacyjny i finalny punkt w narastaniu problemów społecznych ${ }^{7}$,

${ }^{3}$ Ks. Adam Rybicki, Od antropologii do duchowości mężczyzny. Źródła, koncepcje, perspektywy (Pelpin: Wydawnictwo „Bernardinum” 2020), 9.

4 Patrz: Alexander Mitscherlich, Auf dem Weg zur vaterlososen Gesellschaft (München: R. Piper \& Co. Verlag 1963), 188.

5 Wojciech Eichelberger, Zdradzony przez ojca (Warszawa: Wydawnictwo Drzewo Babel, 2015), 23-28.

${ }^{6}$ Mircea Eliade, Inicjacja, obrzędy i stowarzyszenia tajemne. Narodziny mistyczne (Kraków: Wydawnictwo Znak, 1997), 7-8.

7 Paul Josef Cordes, Zagubione ojcostwo (Pelpin: Wydawnictwo „Bernardinum”, 2005), 28. 
związanych z wykorzystywaniem kobiet przez mężczyzn w ekonomii, reklamie etc., czyli jest swego rodzaju zapętleniem przyczyn, reakcji i następstw. Napięcie pomiędzy starym a nowym wzorcem męskości wzmacniane jest także przez relatywizm kulturowy i medialne wypaczenia wzorów męskości promowanych w popkulturze, kinie, obrazach literackich. Szczególnie ważny z pedagogicznego punktu widzenia jest opisany przez ks. Adama Rybickiego problem krzywdzących regulacji prawnych, które, odrzucając znienawidzony patriarchalny model społeczeństwa, w sytuacjach spornych pomiędzy rodzicami ograniczają a priori kontakt ojców z dziećmi. Prawo, które wcześniej dyskryminowało kobiety, zaczyna coraz mocniej dyskryminować mężczyzn. Problematyka ochrony praw dziecka w sytuacji rozstania rodziców jest obszarem, w którym pedagog musi wykazać się szczególną wrażliwością ${ }^{8}$ Kwestie legislacyjne stają się w ten sposób ważnym kontekstem dla kryzysu męskości, wywołanego najgłębszymi frustracjami i zdolnego popchnąć człowieka do desperackich czynów.

Jak zatem w obliczu rozpadu świata odnaleźć sens bycia człowiekiem? Co może być remedium na kulturową wirówkę tożsamości męskiej? Awangarda tradycji. Powrót do źródeł, powrót do źródeł biblijnych i biblijnej teologii męskości. Autor w swej pracy daje tę przestrzeń, daje możliwość zdekonstruowania kulturowych zniekształceń i skonstruowania kategorii męskiej tożsamości zbudowanej na antropologii biblijnej, na teologii duchowości prowadzącej do teologii duchowości mężczyzny. To oryginalne osiągnięcie ks. Adama Rybickiego z pewnością stanowi ważny krok nie tylko dla rozwoju samej teologii duchowości, ale także dla rozwoju idei chrześcijańskiego humanizmu. Wyraża się ono także w umiejętnym budowaniu pomostów pomiędzy źródłami - odczytywaniu i rekonstruowaniu duchowości męskiej na wybranych przykładach Starego i Nowego Testamentu, w tym także na przykładzie męskości Jezusa - a koncepcjami współczesnymi. Biblia nie podaje definicji męskości ani, jak podkreśla Autor, nie definiuje męskiej tożsamości. Pokazuje jednak konkretnych mężczyzn z całą ich realnością, jest także „[...] najważniejszą księgą męskiej duchowości, bo tu właśnie widać najbardziej jaskrawe przykłady męskich zmagań z Bogiem, od wyparcia się Go, aż do całkowitego ogołocenia siebie i ofiarnej miłości do Niego"9. Czytelnik znajdzie zatem próbę uchwycenia istoty męskiej duchowości wybranych postaci Starego Testamentu: Adama, Abrahama, Izaaka, Samsona, Mojżesza, Salomona, Eliasza, Hioba, Jeremiasza, Kaleba, Jonasza i Dawida. Analiza postaci męskich Nowego Testamentu to przede wszystkim rozważanie dotyczące męskości Jezusa i jego postawy wobec kobiet, którą Autor odczytuje w kontekście społecznych i kulturowych uwarunkowań tamtych czasów. Duchowość mężczyzn Nowego Testamentu wyznaczają także postaci: Józefa z Nazaretu, Pawła z Tarsu, Jana Chrzciciela oraz Szymona Piotra. Biblia i opisane

\footnotetext{
${ }^{8}$ Zob. np. pracę dr Małgorzaty Turczyk z Instytutu Pedagogiki UJ: „Ochrona dziecka w sytuacji rozstania rodziców: konceptualizacja przedmiotu badań”. Rocznik Pedagogiczny 42 (2019): 197-204.

${ }^{9}$ Rybicki, Od antropologii, 64.
} 
w niej postacie biblijne mogą być ważnym źródłem odczytywania i rekonstruowania męskiej tożsamości, źródłem inspiracji w poszukiwaniu męskiej duchowości mężczyzny w XXI wieku. Jak podkreśla ks. Adam Rybicki,

nawet pobieżny przegląd przedstawionych tu tylko wybiórczo męskich postaci wskazuje, że pewne wzorce męskości są uniwersalne, sprawdzone przez wieki i przynoszą dobre owoce. Sięganie do nich we współczesności nie jest bezpieczną ucieczką w konserwatyzm, lecz stawianiem sobie trudnego zadania realizacji uniwersalnych męskich cech i wartości w zmieniającym się świecie, w nowych warunkach społeczno-kulturowych i zmieniającej się mentalności ${ }^{10}$.

W drugiej części pracy zatytułowanej Koncepcje Autor idzie właśnie krok dalej i rekonstruuje główne osiągnięcia teologicznej myśli dotyczącej koncepcji męskiej tożsamości i duchowości. Sięga do dzieł antycznych, starożytnych poglądów filozoficznych, myśli biblijnej, świeckich koncepcji średniowiecznych, odrodzeniowych, oświeceniowych, aż do nowożytnych, do dzieł filozoficznych, psychologicznych i kulturowych np. Kartezjusza, Johna Locke’a, Jeana Jacques’a Rousseau, Immanuela Kanta, Artura Schopenhauera, Fryderyka Nietzschego, Herberta Sussmana, Georga Simmela, Michaela Jonesa, Ferdinanda Tönniesa, Zygmunta Freuda, Gunnara Karlssona, Carla Gustawa Junga, Maxa Schelera, Edyty Stein, Simone de Beauvoir, Margaret Mead i wielu, wielu innych. Eksploatując bogate źródła światowej humanistyki, interdyscyplinarne rubieże teologii, filozofii, kultury, politologii, socjologii i psychologii, tropi ślady, które pozwalają mu zrekonstruować dyskurs, jaki toczył się wokół kategorii męskości, i uzasadnić współczesne rozdarcie i spory, w które uwikłana została problematyka budowania tożsamości mężczyzny. Bliska pedagogice jest szczególnie perspektywa psychologiczna, budowana na osiągnięciach duńskiego psychoanalityka i psychologa rozwoju Erika Eriksona. Przyglądając się współczesnym psychospołecznym i kulturowym koncepcjom rozwojowym człowieka, można - przywołując zdanie Lecha Witkowskiego ${ }^{11}$ - potwierdzić sformułowaną przez Jürgena Habermasa hipotezę o istnieniu jednej, wspólnej, komplementarnie opisywanej „logiki rozwojowej”, leżącej u podstaw postfreudowskiej tradycji psychoanalizy Erika H. Eriksona, postpiagetowskiej tradycji psychologii rozwojowej Lawrence’a Kohlberga oraz postmeadowskiej tradycji interakcjonizmu symbolicznego Ervinga Goffmana. „Logika rozwojowa” oznacza przede wszystkim model opisujący proces rozwojowy człowieka jako przechodzenie przez kolejne etapy, związane z rozwijaniem się, różnicowaniem i następowaniem po sobie określonych struktur. Zmiany rozwojowe, zachodzące niejednokrotnie w sposób dyskretny, prowadzą przez kolejne fazy, których kolejności nie można odwrócić, pominąć czy też przeskoczyć. Proces rozwojowy prowadzi, jak podkreśla Lech Witkowski,

10 Tamże, 120.

11 Lech Witkowski, „Młodość i tożsamość w cyklu życia. Zarys koncepcji Erika H. Eriksona”. W: tegoż, Edukacja i humanistyka. Nowe (kon)teksty dla nowoczesnych nauczycieli (Warszawa: IBE, 2007), 310; tenże, Rozwój i tożsamość w cyklu życia. Studium koncepcji E.H.Eriksona (Toruń: Wydawnictwo WIT-GRAF, 2000), 13. 
„przez kryzysy, tzn. rozwiązywanie specyficznych dla danego szczebla problemów rozwojowych odbywa się przez fazę rozmontowywania struktur (destrukturalizacja) oraz częściowego regresu rozwojowego" ${ }^{12}$. Logikę rozwoju wyznacza kierunek coraz większej złożoności strukturalnej oraz wzrost autonomii człowieka.

Koncepcja rozwoju zarysowana przez Erika H. Eriksona doczekała się szerszej recepcji na gruncie pedagogiki przede wszystkim dzięki pracom wspomnianego Lecha Witkowskiego oraz Kazimierza Obuchowskiego czy Aleksandra Nalaskowskiego. W koncepcji Erika H. Eriksona rozwój człowieka opisywany jest poprzez pryzmat dynamiki podejmowanych przez niego w kolejnych fazach zadań egzystencjalnych, ustawicznego zaspokajania potrzeb, których spełnienie zapewnia pomyślny rozwój witalności osobowej. W sytuacji, gdy potrzeba nie zostanie zaspokojona, pojawia się „antypotrzeba” blokująca rozwój i wywołująca kryzys. Rozwój zachodzi zatem w sytuacji napięcia, zagrożenia antypotrzebą, którego granice „stymulacyjnego działania" są bardzo indywidualne. Dynamika rozwojowa polega na narastaniu kolejnych dokonań rozwojowych i skutecznym przezwyciężaniu kryzysów witalności. Jednocześnie każda faza w cyklu życia łączy się z procesualnym kształtowaniem się „residuów” tożsamości ${ }^{13} \mathrm{~W}$ trakcie rozwoju człowieka. W perspektywie koncepcji Erika H. Eriksona residua tożsamości opisywane są w terminach dominującego $\mathrm{w}$ danej fazie zadania egzystencjalnego oraz typu witalności, jakie przynosi jego spełnienie.

Ksiądz Adam Rybicki wykorzystuje koncepcję Erika H. Eriksona do nakreślenia zadań dla fazy nazywanej „tożsamość a niepewność roli” oraz zjawiska rozproszenia tożsamości niektórych mężczyzn i ojców. Zwraca uwagę, że męska tożsamość nie jest fenomenem statycznym, przeciwnie, jest w ciągłym rozwoju wskutek interakcji i relacji społecznych. Jeśli w otoczeniu brakować będzie idei, wzorców, idoli, bohaterów, człowiekowi grozić będzie zwątpienie we własną tożsamość lub jej zagubienie. Natomiast „[...] owocem bogactwa wzorców społecznych męskości i korzystania $z$ nich jest męska integracja i wewnętrzna siła i pewność" ${ }^{14}$. Stąd tak ważne jest owo bogactwo wzorów męskości, których źródłem może być także Biblia. Badania nad współczesnymi koncepcjami męskości ks. Adama Rybickiego lokują się zasadniczo w perspektywie esencjalizmu (biologicznego, teologicznego) lub szeroko pojmowanego nurtu konstruktywizmu, do których należy m.in. teoria socjologiczna Pierre’a Bourdieu ${ }^{15}$. Autorowi udało się wyjść poza tę dychotomię i podstawą swych badań uczynić koncepcję „środka” Richarda Rohra ${ }^{16}$, który określił swoje stanowisko między konstruktywizmem społecznym, uznającym, że

${ }^{12}$ Lech Witkowski, „Edukacja przez pryzmat teorii społecznej Jürgena Habermasa”. W: tegoż, Edukacja i humanistyka, 265-266.

${ }_{13}$ Tenże, „O problemie tożsamości w cyklu życia”. W: tegoż, Edukacja i humanistyka, 335-344.

${ }^{14}$ Rybicki, Od antropologii, 169.

15 Pierre Bourdieu, Męska dominacja (Warszawa: Oficyna Naukowa, 2004).

${ }_{16}$ Richard Rohr, Od mężczyzny dzikiego do mężczyzny mądrego. Refleksje na temat męskiej duchowości (Kraków: Wydawnictwo WAM, 2009). 
męska psychika konstruowana jest przez wpływy kulturowe, a esencjalizmem, który uznaje niezależność męskiej psychiki i tożsamości od uwarunkowań kulturowych, podkreślając podmiotowość mężczyzny zdolną przełamywać determinizm środowiska. Ksiądz Adam Rybicki dopełnia koncepcję franciszkanina Richarda Rohra ważnym kontekstem teologicznym stworzenia człowieka przez Boga, tożsamości człowieka jako kobiety i mężczyzny, który to akt nie wyklucza wolności i możliwości kształtowania własnej tożsamości.

Część trzecia książki, zatytułowana Perspektywy, stanowi swego rodzaju predyktywne otwarcie na możliwe pola badań. Czy na przykład wizja przyszłości świata przyniesie całkowity rozpad męskiej tożsamości związany z niepewnością zawodową, postępującą seksualizacją życia publicznego, upadkiem etosu mężczyzny czy też upowszechnieniem kulturowych konstrukcji płci? Czy tak być musi? W tym miejscu oddaję głos samemu Autorowi, który pisze:

Rolą teologii jest służyć prawdzie, a rozwijanie teologii męskości opartej na antropologii chrześcijańskiej, koncepcji dwóch płci może dopiero w przyszłości jeszcze bardziej ukazać swój veritatis splendor - blask prawdy. Ukazywanie i uzasadnianie wartości męskości oparte na przesłankach biblijnych nie tylko nie zubożają myśli ludzkiej (wbrew pozorom twierdzenia o wielości płci jej nie ubogacają), lecz przeciwnie - wskazują drogi rozwoju ${ }^{17}$.

To optymistyczne spojrzenie ma szansę na realizację także wtedy, gdy upowszechnimy prace takie, jak ks. Adama Rybickiego, które staną się ważnym drogowskazem dla mężczyzn poszukujących swego miejsca w świecie, budujących swą tożsamość w duchu zwrócenia się ku Bogu i źródłom oraz praktykowania żywej religijności.

Warto podkreślić, że Autor, prowadząc badania naukowe nad męską tożsamością i męską duchowością, odczytywaną w kluczu badań interdyscyplinarnych, w których oś wiodącą stanowi teologia duchowości, promuje i twórczo rozwija ideały katolickiej nauki społecznej. We współczesnym świecie to niezwykle ważna pozycja, ułatwiająca budowanie pomostów pomiędzy światem nauki i światem ludzkiego bycia, pomiędzy teologią a światem laickim. Książka ks. Adama Rybickiego reprezentuje także nowoczesny nurt wrażliwości społecznej, która nie rezygnując z niewygodnych dla szerokiej publiczności tez zgodnych z katolicką nauką społeczną, nie rani nikogo. W tym względzie Autor prezentuje postawę pełną miłości i szacunku dla każdej osoby ludzkiej. Na uznanie zasługuje także ogromna erudycja Autora, która charakteryzuje prawdziwych humanistów, swobodnie poruszających się po polach wielu dyscyplin naukowych, zdolnych w swej pracy przekraczać sztuczne granice dyscyplin. Praca pisana jest $\mathrm{z}$ troską o polskiego czytelnika, bowiem zamiarem Autora było również przybliżenie osiągnięć prac autorów publikujących wyłącznie w językach obcych oraz rekonstrukcja światowego dyskursu, który toczy się na marginesach sporów o męskość i tożsamość mężczyzny.

17 Rybicki, Od antropologii, 206. 


\section{Bibliografia}

Bourdieu, Pierre. Męska dominacja, tłum. Lucyna Kopciewicz. Warszawa: Oficyna Naukowa, 2004. Cordes, Paul Josef. Zagubione ojcostwo, tłum. Jan Koźbiał. Pelpin: Wydawnictwo „Bernardinum”, 2005. Eichelberger, Wojciech. Zdradzony przez ojca. Warszawa: Wydawnictwo Drzewo Babel, 2015.

Eliade, Mircea. Inicjacja, obrzędy i stowarzyszenia tajemne. Narodziny mistyczne, tłum. Krzysztof Kocjan. Kraków: Wydawnictwo Znak, 1997.

Mitscherlich, Alexander. Auf dem Weg zur vaterlososen Gesellschaft. München: R. Piper \& Co. Verlag, 1963.

Nalaskowski, Aleksander. „Alternatywność szkoły jako kolejny etap jej kryzysu”. W: tegoż, Widnokręgi edukacji, 311-326. Kraków: Impuls, 2002.

Rohr, Richard. Od mężczyzny dzikiego do mężczyzny mądrego. Refleksje na temat męskiej duchowości, tłum. Grzegorz Baster. Kraków: Wydawnictwo WAM, 2009.

Rybicki, Adam. Od antropologii do duchowości mężczyzny. Źródła, koncepcje, perspektywy. Pelpin: Wydawnictwo „Bernardinum”, 2020.

Turczyk, Małgorzata. „Ochrona dziecka w sytuacji rozstania rodziców: konceptualizacja przedmiotu badań". Rocznik Pedagogiczny 42 (2019): 197-204.

Witkowski, Lech. Rozwój i tożsamość w cyklu życia. Studium koncepcji E.H. Eriksona. Toruń: Wydawnictwo WIT-GRAF, 2000.

Witkowski, Lech. „Młodość i tożsamość w cyklu życia. Zarys koncepcji Erika H. Eriksona”. W: tegoż, Edukacja i humanistyka. Nowe (kon)teksty dla nowoczesnych nauczycieli. Warszawa: IBE, 2007.

Witkowski, Lech. „Edukacja przez pryzmat teorii społecznej Jürgena Habermasa”. W: tegoż, Edukacja $i$ humanistyka. Nowe (kon)teksty dla nowoczesnych nauczycieli. Warszawa: IBE, 2007.

Witkowski, Lech. „O problemie tożsamości w cyklu życia”. W: tegoż, Edukacja i humanistyka. Nowe (kon)teksty dla nowoczesnych nauczycieli. Warszawa: IBE, 2007.

Anna Sajdak-Burska ${ }^{18}$

Uniwersytet Jagielloński

http://orcid.org/0000-0002-0156-3986

${ }^{18}$ Dr hab. Anna Sajdak-Burska - profesor nadzwyczajny w Instytucie Pedagogiki Uniwersytetu Jagiellońskiego, Kierownik Zakładu Pedagogiki Szkolnej i Dydaktyki Akademickiej, Kierownik Studiów Doktoranckich na Wydziale Filozoficznym UJ, członek Rady Naukowej Instytutu Badań Edukacyjnych w Warszawie. Adres do korespondencji: Instytut Pedagogiki UJ, ul. S. Batorego 12, 31-135 Kraków; e-mail: a.sajdak@uj.edu.pl. 